\title{
A COMPARATIVE STUDY OF THE COAGULATION BEHAVIOUR OF MARINE MICROALGAE
}

\author{
R. J. ELDRIDGE ${ }^{1}$, D. R. A. HILL ${ }^{1,2}$, B. R. GLADMAN ${ }^{1,2^{*}}$ \\ ${ }^{1}$ Department of Chemical Engineering, Monash University, Clayton, Australia
}

\begin{abstract}
Coagulation is an important step in the harvesting of algal biomass. This paper presents experimental results for a variety of prospective marine microalgal species using several inorganic and organic coagulants. Tetraselmis suecica and Chlorococcum sp. are readily coagulated using alum or iron(III) sulfate without any $\mathrm{pH}$ adjustment; doses of 3-5 $\mathrm{mg} \mathrm{L}^{-1}$ or $0.2 \mathrm{mmol} \mathrm{m}^{-2}$ of $\mathrm{Al}^{3+}$ or $\mathrm{Fe}^{3+}$ yielding cell recoveries above $90 \%$ after only 5 min settling. Nannochloropsis salina, Dunaliella tertiolecta and Isochrysis galbana are harder to coagulate and require at least two times more coagulant to achieve similar recoveries. Several cationic polyacrylamides were investigated but were less effective than $\mathrm{Al}^{3+}$ or $\mathrm{Fe}^{3+}$. Addition of $\mathrm{NaOH}$ to control $\mathrm{pH}$ improved the coagulation efficiency of $N$. salina but not of D. tertiolecta. The high coagulant demand of $N$. salina is due in part to its small size and large surface area, while that of $D$. tertiolecta may be attributable to its high production of extracellular polymer. The implications of cell surface properties for coagulation efficiency are discussed. At the coagulant doses used herein settled cells remain viable. Resuspension is a potential problem with some species, arising either from cell motility or from flotation of flocs by oxygen bubbles generated by photosynthesis. These effects can be eliminated by small additions of chlorine or by settling the algae in the dark.
\end{abstract}

Key words--microalgae, dewatering, harvesting, coagulation, flocculation, biofuels

\footnotetext{
*Corresponding author:

${ }^{2}$ Present address: Department of Chemical and Biomolecular Engineering, The University of Melbourne, Melbourne, Australia

Tel.: +61 38344 4888; fax: +61 83444153

E-mail address: bgladman@unimelb.edu.au
} 


\section{INTRODUCTION}

The harvesting and dewatering of microalgae is a key stage in converting algal biomass into biofuel (McGraw 2009). To be a viable fuel source, whether via fermentation, anaerobic digestion, gasification or transesterification of algal lipids, the cells must be recovered from a highly dilute culture $\left(\sim 0.1\right.$ to $\left.1 \mathrm{~g} \mathrm{~L}^{-1}\right)$ and concentrated to a thickened paste. While centrifugation is effective at dewatering algal suspensions, the cost of processing large volumes of low solid content is too high for a relatively low value biofuel product. Preconcentration from between 50-200 fold can be achieved via gravity sedimentation (Knuckey et al. 2006) or flotation (Henderson et al. 2008). In both sedimentation and flotation processes, aggregation of individual cells is a requirement. Coagulation is a process used to destabilise cells so that when two or more cells are brought into contact they adhere. Multiple collisions result in a large multicellular aggregate that will settle at a rate increasing in proportion to the square of the floc diameter.

Several types of coagulant are commercially available including: polyvalent metal salts, synthetic (often acrylamide-based) polymeric flocculants and modified natural polymers referred to as bioflocculants, such as chitosan and cationic starches. Novel bioflocculants extracted from bacteria or yeast cells are of interest (Levy et al. 1992, Salehizadeh and Shojaosadati 2001) but are expensive to produce (Williams and Laurens 2010). Synthetic polymeric flocculants can be effective but their ability to consistently flocculate microalgal cells under all conditions has not been proven; for example, Bilanovic et al. (1988) reported poor recovery of marine algae using cationic polyacrylamide based flocculants attributing this to tight coiling of the flexible polymer chains at high ionic strength while chitosan, despite being of lower molecular weight, has a more rigid backbone, and is therefore less affected by ionic strength. However, Pushparaj et al. (1993) later reported recoveries of around $70 \%$ for the marine microalga Tetraselmis suecica dosing $1 \mathrm{mg} \mathrm{L}^{-1}$ of an acrylamide-based cationic flocculant. It is possible that this higher removal was due to charge neutralisation rather than polymer bridging, especially if the charge density of the polymer was reasonably high. Small amounts of high molecular weight polymer, added in combination with a primary coagulant can have a beneficial effect on coagulation, yielding larger, stronger flocs that settle faster (Bolto and Gregory 2007).

The coagulation and flocculation behaviour of microalgal cells has been described by several authors, mainly in relation to purification of potable water or the production of aquaculture feeds (Tenney et al., 1969; McGarry, 1970; Bernhardt and Clasen, 1991; Pieterse and Cloot, 1997; Knuckey et al., 2006). Aluminium sulfate (alum, $\left.\mathrm{Al}_{2}\left(\mathrm{SO}_{4}\right)_{3}\right)$, ferric sulfate $\left(\mathrm{Fe}_{2}\left(\mathrm{SO}_{4}\right)_{3}\right)$ and chitosan have all been used to recover algal cells. However, reported recoveries vary widely, even for the same species, and discrepancies are difficult to explain because experimental conditions either varied or were not specified. Coagulation is a complex process and several parameters can affect the outcome including: hydrodynamic conditions, temperature, $\mathrm{pH}$ and type of coagulant. The concentration of cells, their size and surface composition are also important. Likewise, the culture age, growth phase and growth medium composition can also affect coagulation (Lubián 1989, Morales et al. 1985).

Page 2 of 27 
The aim of this work was to investigate coagulation of several marine microalgae. Five species representing four algal classes (Chlorophyceae, Prasinophyceae, Eustigmatophyceae and Prymnesiophyceae) were studied. The five species vary markedly in cell size, cell wall structure, surface chemistry and motility. This comparative study aimed to clarify the currently poorly understood relationships between algal physicochemical attributes and coagulation behaviour (Williams and Laurens, 2010).

\section{MATERIALS AND METHODS}

Tetraselmis suecica (Kylin) Butcher and Chlorococcum sp. were isolated from a photobioreactor at the Hazelwood Power Station, Hazelwood, Victoria, in September 2009; Dunaliella tertiolecta Butcher was collected and isolated from Port Phillip Bay, Victoria, in December 2009; Isochrysis galbana Parke was isolated from the Wimmera River at Jeparit, Victoria, in April 2010 and Nannochloropsis salina Hibberd was kindly provided by Professor John West, University of Melbourne from his private collection.

\section{1.}

Cultures were maintained in a modified 'f-medium' (Guillard and Ryther, 1962). The medium consisted of $30 \mathrm{~g}$

$\mathrm{L}^{-1}$ sea salt (Prodac, Cittadella, Italy), $250 \mathrm{mg} \mathrm{L}^{-1} \mathrm{NaNO}_{3}, 18.0 \mathrm{mg} \mathrm{L}^{-1} \mathrm{KH}_{2} \mathrm{PO}_{4}, 10 \mathrm{mg} \mathrm{L}^{-1} \mathrm{MgSO}_{4} .7 \mathrm{H}_{2} \mathrm{O}, 9.0 \mathrm{mg}$ $\mathrm{L}^{-1}$ iron(III) citrate $\mathrm{C}_{6} \mathrm{H}_{5} \mathrm{O}_{7} \mathrm{Fe}, 9.0 \mathrm{mg} \mathrm{L}^{-1}$ citric acid $\mathrm{C}_{6} \mathrm{H}_{8} \mathrm{O}_{7}, 0.200 \mathrm{mg} \mathrm{L} \mathrm{L}^{-1} \mathrm{MnCl}_{2} .4 \mathrm{H}_{2} \mathrm{O}, 0.023 \mathrm{mg} \mathrm{L}$ $\mathrm{ZnSO}_{4} .7 \mathrm{H}_{2} \mathrm{O}, 0.011 \mathrm{mg} \mathrm{L} \mathrm{CoCl}_{2} \cdot 6 \mathrm{H}_{2} \mathrm{O}, 0.005 \mathrm{mg} \mathrm{L}^{-1} \mathrm{CuSO}_{4} \cdot 5 \mathrm{H}_{2} \mathrm{O}, 0.008 \mathrm{mg} \mathrm{L}^{-1} \mathrm{Na}_{2} \mathrm{MoO}_{4} .2 \mathrm{H}_{2} \mathrm{O}, 0.00065$ $\mathrm{mg} \mathrm{L}^{-1} \mathrm{H}_{2} \mathrm{SeO}_{3}$ and traces of vitamin $\mathrm{B} 12$, biotin and thiamine.

Cultures were grown either outdoors in photobioreactors (PBRs) or in a laboratory growth cabinet (Labec, Laboratory Equipment $\mathrm{P} / \mathrm{L}$, Australia) maintained at $20^{\circ} \mathrm{C} \pm 0.1^{\circ} \mathrm{C}$ and a $16: 8$ light dark cycle with white fluorescent lights and a photon flux of $\sim 60 \mu \mathrm{mol}$ photon. $\mathrm{m}^{-2} \cdot \mathrm{s}^{-1}$. Growth cabinet cultures were grown in $10 \mathrm{~L}$ glass bottles. Outdoor cultures were grown in semi-sealed $80 \mathrm{~L}$ hanging polyethylene tubular photobioreactors located in a north-facing position. Both laboratory and outdoor cultures were sparged with compressed air to keep the cells in suspension and provide a source of carbon in the form of $\mathrm{CO}_{2}$ at atmospheric levels. A positive pressure was maintained in the bags, reducing the likelihood of airborne contamination. Temperature, $\mathrm{pH}$ and optical density $\left(\mathrm{OD}_{750}\right)$ were measured daily. During the period that cultures were harvested for coagulation experiments, temperatures in the outdoor PBRs ranged from 8 to $33^{\circ} \mathrm{C}$. All flocculation work was carried out at room temperature. The mean length of daylight over this period ranged from $\sim 10$ to $\sim 12 \mathrm{~h}$. Unless otherwise noted, samples used in experiments were harvested during the log phase of growth, stored at room temperature in opaque 20L plastic drums and used within $8 \mathrm{~h}$.

\subsection{Flocculation}


Stock solutions of aluminium sulfate, $\left(10 \mathrm{~g} \mathrm{Al}^{3+} \mathrm{L}^{-1}\right)$ and iron(III) sulfate $\left(2 \mathrm{~g} \mathrm{Fe}^{3+} \mathrm{L}^{-1}\right)$ were prepared by dissolving the required weight of dry solid in deionized water. Stock polyacrylamide solutions $\quad\left(5 \mathrm{~g} \mathrm{~L}^{-1}\right.$ Magnafloc 919, Ciba Specialty Chemicals) were prepared similarly. Working solutions of each coagulant were prepared by dilution as required on the day of the experiment. Sodium hypochlorite solution $(12.5 \% \mathrm{w} / \mathrm{v}$ available chlorine) was diluted tenfold prior to dosing. Sodium hydroxide was dosed as a $1 \mathrm{M}$ solution.

Coagulation experiments were performed with a six-position flocculator (Model JLT6, VELP Scientifica, Italy). One litre aliquots of harvested algal culture were dosed with coagulant solution at a stirring speed of $125 \mathrm{rpm}$. After $2 \mathrm{~min}$ the speed was lowered to $50 \mathrm{rpm}$ for $15 \mathrm{~min}$. The coagulated cells were allowed to settle and samples taken at mid-depth after $5 \mathrm{~min}$ and in most cases also at longer times. Cell recoveries following coagulation were determined by measuring optical densities at $750 \mathrm{~nm}$. The ratio of coagulant to cell dry weight (DW) was estimated from initial OD values using a conversion factor derived from a number of concurrent OD and DW determinations (Table 1). The coagulation efficiency or cell recovery is the percentage reduction of the initial cell concentration calculated using the following equation:

$$
\text { Recovery\% }=\left(1-\frac{\mathrm{OD}_{\mathrm{f}}(750 \mathrm{~nm})}{\mathrm{OD}_{0}(750 \mathrm{~nm})}\right) \times 100
$$

where $\mathrm{OD}_{\mathrm{o}}$ is the absorbance at $750 \mathrm{~nm}$ of the initial culture and $\mathrm{OD}_{\mathrm{f}}$ is the absorbance at $750 \mathrm{~nm}$ of sampled supernatant after a specified period of settling.

\subsection{Dry Weight (DW) determinations}

Cell dry weight measurements were made in triplicate by filtering $20 \mathrm{~mL}$ of culture onto a pre-dried and preweighed glass fibre filter (Whatman, $\mathrm{GF} / \mathrm{C}$ ), rinsing with $20 \mathrm{~mL}$ of $0.5 \mathrm{M}$ ammonium formate solution and

drying the filter overnight to constant weight in an oven at $60^{\circ} \mathrm{C}$. The dried filters were then allowed to cool in a dessicator after which they were reweighed to calculate the cell dry weight per medium unit volume $\left(\mathrm{g} \mathrm{DW} \mathrm{L}^{-1}\right)$.

\subsection{DOC Analysis}

T. suecica culture was harvested at different stages of the growth cycle over a 28 day period and concentrated using crossflow microfiltration (Millipore Pellicon). The filtrates were analysed for dissolved organic carbon (DOC) by the Water Studies Centre (WSC), Monash University, using a Shimadzu TOC-V instrument. Five harvests over a 16 day period from similar D. tertiolecta and N. salina cultures were centrifuged at $2560 \mathrm{x} g$ and the centrate further purified by filtration (Millipore HAWP, $0.45 \mu \mathrm{m}$ ) and analysed for DOC. One Chlorococcum sample harvested at late stationary phase was also analysed for DOC.

\subsection{Residual coagulant}


T. suecica cultures containing $0.34 \mathrm{~g} \mathrm{~L}^{-1}$ were coagulated with alum or ferric sulfate $\left(1-6 \mathrm{mg} \mathrm{L}^{-1}\right.$ as $\left.\mathrm{M}^{3+}\right)$ and the supernatants analysed for $\mathrm{Al}$ or $\mathrm{Fe}$ respectively after further clarification by centrifuging for $30 \mathrm{~min}$ at $4500 \mathrm{rpm}$. The sediments were also analysed after acid digestion.

\subsection{Surface area calculations}

For the species studied in this work, the surface area (SA) per cell varies by a factor of 15 , from $20.6 \mu \mathrm{m}^{2}$ for $N$. salina to $302 \mu \mathrm{m}^{2}$ for Chlorococcum sp. (Table 1). The surface areas were calculated from the average measurements of up to 360 individual cells for each species. Surface areas of ellipsoidal cells were calculated according to the formula:

$$
S A=4 / 3 \check{s}\left(a^{p} b^{p}+a^{p} c^{p}+b^{p} c^{p}\right)^{1 / p}
$$

where $a, b$ and $c$ are the semi-axes and $p=1.6075$.

The surface area of Chlorococcum was calculated from the formula for the surface area of a sphere $(\mathrm{SA}=4 \pi \mathrm{r} 2)$. Surface areas per gram of dry matter, determined from a calculation of the number of cells constituting a gram of dry weight biomass for each species, vary by a factor of 6, being least for Chlorococcum sp. and T. suecica and greatest for I. galbana and N. salina.

\subsection{Chlorophyll fluorescence measurements}

Maximum photochemical quantum yields of PSII were measured directly on settled cultures that had been covered (dark adapted) for 30 minutes. Measurements were made with a pulse-amplitude modulation fluorescence analyser (Mini-PAM, Walz, Germany).

\section{RESULTS}

\section{Comparison of coagulation behaviour between species using metal salts}

A representative selection of coagulation results is presented in Table 2. In this table and in Figs 1 to 5, coagulant doses are expressed as $\mathrm{mg} \mathrm{L}^{-1}$, which gives an indication of the comparative efficiency of coagulation for the different species or the relative effectiveness of different coagulants over a narrow range of cell concentration. In later figures, dose is expressed as mmol of coagulant per dry weight gram of biomass or mmol per unit cell surface area to aid interpretation of results over a wider range of conditions.

Tetraselmis suecica (Prasinophyceae) 
At $1-5 \mathrm{mg} \mathrm{Al}{ }^{3+} \mathrm{L}^{-1}$, cell separations of $90-95 \%$ were obtained after only 5 minutes settling in jar tests, with the optimum dose being about $3 \mathrm{mg} \mathrm{Al}^{3+} \mathrm{L}^{-1}$ (Fig 1). At $5 \mathrm{mg} \mathrm{Al}^{3+} \mathrm{L}^{-1}$, the $\mathrm{pH}$ decreased by $0.5-0.8$ units from an initial value of 8.5-9. Ten $1 \mathrm{~L}$ aliquots of $T$. suecica culture harvested on the same day $\left(0.34 \mathrm{~g} \mathrm{~L}^{-1}\right)$ were each treated identically with $4 \mathrm{mg} \mathrm{Al}^{3+} \mathrm{L}^{-1}$, yielding a mean cell recovery of $94.2 \%$ after 5 minutes settling, with a standard deviation of $1.8 \%$. Recovery was further improved by combining $\mathrm{Al}^{3+}$ with 1 or $2 \mathrm{mg} \mathrm{L}^{-1}$ of the anionic polyacrylamide Magnafloc 919. The most dramatic effect of combining alum with Magnafloc corresponded to a low alum dose and a low concentration of $T$. suecica cells, where the recovery increased from 24.6 to $96.2 \%$. Cells coagulated with $\mathrm{Al}^{3+}$ at low coagulant:DW ratios began to redisperse after about 15 min but at $6 \mathrm{mg} \mathrm{Al}^{3+} \mathrm{L}^{-}$ ${ }^{1}$ no redispersion was evident after at least one hour. Microscopic examination of the sediment showed qualitatively a diminishing number of actively-swimming individual cells as dose increased, until virtually all cells were immobilised in $\mathrm{Al}(\mathrm{OH})_{3}$ flocs at high dose. Coagulation caused no reduction in cell viability, however, as measured by photosynthetic yield at doses up to at least $20 \mathrm{mg} \mathrm{Al}^{3+} \mathrm{L}^{-1}$. The lack of redispersion at higher coagulant dose is therefore more likely to be related to the structure and strength of the aggregate and enmeshment of cells within the hydroxide floc.

Dosing T. suecica suspensions with iron(III) sulfate at 2-6 $\mathrm{mg} \mathrm{Fe}^{3+} \mathrm{L}^{-1}$ achieved similar cell recovery to alum (91-97\%) after 5 min settling (Fig 1). The pH dropped by about 1 unit at $6 \mathrm{mg} \mathrm{Fe}^{3+} \mathrm{L}^{-1}$. At doses of 1-2 $\mathrm{mg} \mathrm{Fe} \mathrm{F}^{3+}$ $\mathrm{L}^{-1}$, settled cells began to redisperse after as little as 15 minutes, but above $3 \mathrm{mg} \mathrm{Fe} \mathrm{Fe}^{3+} \mathrm{L}^{-1}$ there was no redispersion of individual cells. At dosages above $3 \mathrm{mg} \mathrm{Fe}^{3+} \mathrm{L}^{-1}$, the smaller flocs continued to settle over time, such that recoveries exceeded $99 \%$ after $1 \mathrm{~h}$ (Fig. 2). At the highest Fe dose a few of the settled flocs could be observed floating to the surface as a consequence of entrapped bubbles, presumably oxygen generated by photosynthesis. This effect was minimised in one batch of $T$. suecica by keeping the suspension in the dark during coagulation and settling. Microscopic examination of the algal-iron sediment showed some actively swimming cells at doses up to $5 \mathrm{mg} \mathrm{L}^{-1}$ in addition to the aggregates or flocs. Most cells were static within the aggregates, although some were observed to oscillate vigorously in place. Once again, there was no reduction in cell viability at doses up to $20 \mathrm{mg} \mathrm{L}^{-1}$.

The cationic flocculants Zetag 7550 and 7570 were less effective than either $\mathrm{Al}^{3+}$ or $\mathrm{Fe}^{3+}$. 5-minute cell recoveries were still acceptable, however, at doses of $1-5 \mathrm{mg} \mathrm{L}^{-1}$ but were variable, ranging from below $80 \%$ (similar to those reported by Pushparaj et al.) to above $89 \%$. The reason for this variability is unclear, but experiments appeared to rule out either the age of the polymer solution or storage time of the culture post-harvest as a causative factor. Recovery increased with longer settling times, usually exceeding 90\% after 30 min (Fig. 3). The polymeric flocculants had negligible effect on the $\mathrm{pH}$ of the suspension (Fig. 1). Of a series of acrylamide copolymers having similar molecular architecture but varying charge density (Zetag 8110, 8140, 8180, 8190) only the polymer with the highest charge (8190) achieved 5-min recoveries above 90\%, and then only at doses of 8-10 mg L ${ }^{-1}$ (Fig. 4). 


\section{Chloroccocum sp. (Chlorophyceae)}

Chlorococcum $s p$. is a non-motile species with spherical cells measuring, on average, $9.6 \mu \mathrm{m}$ in diameter. Motile zoospores or gametes form part of the life cycle in many Chlorococcum species, but were extremely rare in this strain. The cells are robust, possessing a conspicuous and rigid cell wall composed of roughly half cellulose and half hydroxyproline-rich glycoprotein (Miller 2006). This species commonly forms aggregates due to incomplete cell division, so that cultures usually have a mix of 4,8 and often 16 cell "colonies". It is also usual for much larger aggregates to form naturally in old or stationary phase cultures. Without constant agitation, these multi cell colonies of Chlorococcum settle rapidly in culture.

Cultures of Chlorococcum sp. were markedly alkaline, with the $\mathrm{pH}$ reaching 9.4-9.5. The coagulation behaviour was similar to that of $T$. suecica. At an initial DW concentration of $0.415 \mathrm{~g} \mathrm{~L}^{-1}$, an optimum $\mathrm{Fe}^{3+}$ dose was $3 \mathrm{mg}$

$\mathrm{L}^{-1}$, corresponding to a cell recovery of $>97 \%$ after 5 min settling and $99 \%$ after $1 \mathrm{~h}$. The very high recoveries of this species are not surprising given this organism's tendency to settle due to its larger size, and mass density, especially in older cultures. However, sedimentation of dispersed individual cells or dividing colonies typically occurs over hours rather than minutes. Figs 6 and 7 show the effectiveness of $\mathrm{Fe}^{3+}$ and $\mathrm{Al}^{3+}$ in coagulating Chlorococcum $s p$ and T. suecica, among others. Both species showed similar susceptibility to overdosing, the decline in recovery becoming increasingly marked as the coagulant dose increased and therefore $\mathrm{pH}$ decreased. Alum was less effective than ferric sulfate at recovering Chlorococcum sp at low dosages and short settling times but at 4-6 $\mathrm{mg} \mathrm{Al}^{3+} \mathrm{L}^{-1}$ the recovery exceeded $90 \%$ after $5 \mathrm{~min}$ and again reached $99 \%$ after $1 \mathrm{~h}$. There was no redispersion of Chlorococcum at any coagulant dose due to the lack of motility in this organism. Furthermore, very little resuspension of settled flocs by flotation was observed except at the highest $\mathrm{Fe}^{3+}$ dose. This indicates that the Chlorococcum aggregates are either larger or denser in mass than those corresponding to $T$. suecica and that a high mass ratio of metal hydroxide precipitate to cell number was necessary in order for the flocs to float.

\section{Nannochloropsis salina (Eustigmatophyceae)}

Nannochloropsis salina is a very small, rapidly-growing non-motie species. The cells are sub-ellipsoid and slightly flattened, measuring on average about $3 \mu \mathrm{m}$ long, $2.6 \mu \mathrm{m}$ wide and $2 \mu \mathrm{m}$ deep. The cells possess a cell wall that appears as a compact, layered, fibrillar matrix composed of highly resistant, nonhydrolyzable biopolymers, termed algaenans (Gelin et al. 1996, 1999). N. salina cultures harvested at a dry weight concentration of $0.5 \mathrm{~g} \mathrm{~L}^{-1}$ and $\mathrm{pH}>9$ had a higher coagulant demand than either T. suecica or Chlorococcum sp. (Table 2, Figs 6, 7). This is presumably due, at least in part, to its small size and high surface area. Good

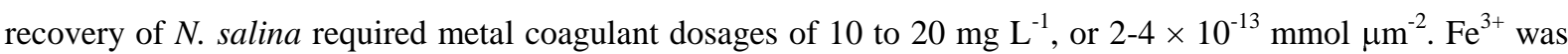
more effective than $\mathrm{Al}^{3+}$, with $>95 \%$ recovery in this dose range compared to $87 \%$ with alum. Settling times of 15 min gave better recoveries than 5 min, i.e. there was no redispersion. Cationic polyacrylamide was ineffective at doses at least up to $20 \mathrm{mg} \mathrm{L}^{-1}$ (Table 2), presumably due to the higher number of cells per unit volume and/or increased surface area. $N$. salina coagulated with alum was slow to settle, and unlike $T$. suecica settling was not 
markedly accelerated by addition of anionic polyacrylamide, although $5 \mathrm{~min}$ recoveries did improve for coagulant doses where coagulation was already effective, i.e. $8-12 \mathrm{mg} \mathrm{M}^{3+} \mathrm{L}^{-1}$. A low cell or floc density may have contributed to the slow settling rate. As with T. suecica coagulation, after a period of time, settled flocs were again observed to float, confirming that addition of metal salt in the dose range indicated did not appear to affect the cells ability to photosynthesise.

The higher coagulant doses required with $N$. salina resulted in a severe $\mathrm{pH}$ drop (by 1-1.8 and $\sim 3$ units at $20 \mathrm{mg}$ $\mathrm{L}^{-1}$ of $\mathrm{Fe}^{3+}$ and $\mathrm{Al}^{3+}$, respectively). The existence of an optimum $\mathrm{Al}^{3+}$ dose at 8-12 $\mathrm{mg} \mathrm{L}^{-1}$ for a cell concentration of $0.34 \mathrm{~g} \mathrm{~L}^{-1}\left(\sim 1-1.3 \mathrm{mmol} \mathrm{g}^{-1}\right.$, Table 2$)$ is probably related to the decrease in $\mathrm{pH}$ at higher doses. At this cell concentration the $\mathrm{pH}$ fell from an initial 9.4 to 8.3, 7.4 and 6.1 at $\mathrm{Al}^{3+}$ doses of 8, 12 and $20 \mathrm{mg} \mathrm{L}^{-1}$. Even at the optimum alum dose, N. salina is markedly less effectively coagulated than T. suecica or Chlorococcum sp. at the same $\mathrm{pH}$. This finding can be attributed to the difference in surface area as noted above and possibly also to differences in surface functionality. It was expected that coagulant demand would increase with cell concentration but as the culture aged, and therefore cell number increased, coagulation performance actually improved, i.e. higher removals were observed for similar coagulant dosages. This could be due in part to improved coagulation kinetics in the denser culture, or accumulation of extracellular organics that affect cell removal. However, it is noteworthy that the culture $\mathrm{pH}$ and buffer capacity also increased with cell concentration, allowing higher coagulant dosages to be applied while maintaining a final $\mathrm{pH}$ within the range at which alum is effective. Thus no optimum dose was observed up to $20 \mathrm{mg} \mathrm{Al}^{3+} \mathrm{L}^{-1}$ when the cell concentration in the culture had increased to $0.41 \mathrm{~g} \mathrm{~L}^{-1}$ (Table 2, Fig. 7). From an initial 9.8 the $\mathrm{pH}$ only fell to $8.8,8.4$ and 6.9 at 8,12 and $20 \mathrm{mg} \mathrm{Al}^{3+} \mathrm{L}^{-1}$. The corresponding values in the $0.34 \mathrm{~g} \mathrm{~L}^{-1}$ sample were 9.4, 8.3, 7.4 and 6.1.

Addition of $\mathrm{NaOH}$ to adjust the $\mathrm{pH}$ substantially improved cell recovery when the coagulant was $\mathrm{Fe}^{3+}$ (Fig. 8). Optimisation experiments (not shown) indicated an optimum $\mathrm{pH}$ above 9 for the $N$. salina $/ \mathrm{Fe}^{3+}$ combination, with a 5-min cell recovery exceeding $98 \%$ at $12 \mathrm{mg} \mathrm{L}^{-1}\left(0.42 \mathrm{mmol} \mathrm{g}^{-1}\right)$ and $\mathrm{pH} 9.3$. There was a similar but less marked effect with $\mathrm{Al}^{3+}$ : cell recovery reached $93 \%$ at $14 \mathrm{mg} \mathrm{L}^{-1}\left(1.0 \mathrm{mmol} \mathrm{g}^{-1}\right)$ when the final $\mathrm{pH}$ was adjusted to 8.5 (Fig. 9). The optimum $\mathrm{pH}$ for $\mathrm{Al}^{3+}$ coagulation of $N$. salina appears to be in the range $\mathrm{pH}$ 7.0-7.6 but the effect of $\mathrm{pH}$ is small between $\mathrm{pH} 6.8$ and 8.5 .

\section{Dunaliella tertiolecta (Chlorophyceae)}

Dunaliella tertiolecta possesses two conspicuous flagella and is perpetually motile, even during cell division. The cells are described as being "naked," meaning that they do not possess a cell wall. Transmission electron microscopic images show, however, that the cell surface has an inconspicuous layer of very fine fibrillar material (Oliveira et al. 1980, Borowitzka and Siva 2007). The chemical nature of this material is unknown, but in a preliminary histological examination, Oliveira et al. (1980) suggested that it possesses a proteinaceous component. The absence of a cell wall means that the cells are fragile and that the cell shape is somewhat elastic. The pattern of preservation of the surface coat of $D$. tertiolecta suggests a relatively high anionic charge density 
and simultaneously an uneven distribution of polyanionic carbohydrate residues throughout the surface matrix (Oliveira et al., 1980). The lack of a cell wall may, in part, explain the observation that as much as $66 \%$ of the $\mathrm{CO}_{2}$ fixed in photosynthesis finds its way into the culture medium as dissolved organic carbon (Huntsman, 1972).

D. tertiolecta shows qualitatively very different coagulation behaviour compared to the other species investigated (Figs 6,7) with virtually no coagulation below a threshold dose, followed by a steep rise to high recoveries at doses above $8 \mathrm{mg} \mathrm{L}^{-1}$, especially of $\mathrm{Al}^{3+}$. The threshold dose increased with culture age along with the concentration of cells in culture, doubling as the $\mathrm{OD}_{750}$ increased from 0.49 to 0.64 for both $\mathrm{Al}^{3+}$ and $\mathrm{Fe}^{3+}$. The relatively small increase in cell concentration, from 0.25 to $0.32 \mathrm{~g} \mathrm{~L}^{-1}$, over the same time period would not be expected to produce such a marked increase in coagulant demand, and release of soluble extracellular polymeric substances (EPS) by $D$. tertiolecta cells seems a more likely explanation. In contrast to $N$. salina, adding $\mathrm{NaOH}$ to raise the $\mathrm{pH}$ was detrimental to coagulation: for a $D$. tertiolecta culture with $0.31 \mathrm{~g} \mathrm{~L}^{-1}$, cell recovery after dosing with $20 \mathrm{mg} \mathrm{Fe}^{3+} \mathrm{L}^{-1}$ was $54 \%$ at $\mathrm{pH} 6.6$ but fell to $33 \%$ at 7.4 and $24 \%$ at 8.65 . Resuspension of $D$. tertiolecta was not observed after coagulation with either $\mathrm{Al}^{3+}$ or $\mathrm{Fe}^{3+}$. Maximum photochemical quantum yield of PS II measurements indicated increasing levels of stress to PS II with increasing coagulant doses: yields decreased from 0.7 at low coagulant dose to 0.6 at $12 \mathrm{mg} \mathrm{Al}^{3+} \mathrm{L}^{-1}$ and 0.4 at $20 \mathrm{mg} \mathrm{Fe}^{3+} \mathrm{L}^{-1}$. These levels were not enough to result in any loss of vitality - cells were able to recover rapidly when exposed to fresh culture medium.

Measurements of DOC in filtered culture medium (Fig.10) suggest that D. tertiolecta produced far more EPS than T. suecica, N. salina or Chlorococcum sp. and that the EPS concentration increased steeply after about two weeks. The $D$. tertiolecta culture contained high levels of bacteria, presumably as a consequence of, and supported by, the high organic carbon concentration. Polyvalent metal ions or their hydrolysis products could become bound to soluble EPS or to bacterial cell surfaces or both. The increase in coagulant demand may therefore result largely from the levels of EPS, either directly or indirectly.

\section{Isochrysis galbana (Prymnesiophyceae)}

Isochrysis galbana is a small $(4-5 \mu \mathrm{m})$, motile species with two relatively short flagella and a minute flagellalike organelle called a haptonema. The haptonema is not involved in motility; rather, it is an organelle used for attachment and/or for "catching" bacteria. I. galbana does not have a cell wall, but possesses imbricate layers of non-mineralized, minute plate-like scales that are glycoprotein in nature (Parke 1949, Green and Pienaar 1977, pers. obs).

I. galbana proved resistant to coagulation, with recoveries increasing only slowly with increasing coagulant dose (Table 2). This can be attributed in part to its small size, but since I. galbana has a higher coagulant demand than the even smaller $N$. salina (Figs 6,7) other factors must also be at work. It may be significant that the two species most resistant to coagulation (I. galbana and D. tertiolecta) are both motile. A hydrophilic glycoprotein 
surface layer would be expected to contribute to the stability of dispersed I. galbana cells. In the case of alum, $\mathrm{pH}$ was observed to drop steeply with increasing dose, which, as with $N$. salina, would reduce the effectiveness of coagulation.

The coagulation profile seems to be more like Nannochloropsis than the others - similar small size, similar demand. The nature of the scaly wall may also be involved and is discussed below. There will also be, as in other species, the production of EPS. While we did not measure the DOC in our cultures of $I$. galbana, extracellular carbohydrate production has been assessed in this species by other authors (Guillard and Wangersky 1958, Marker 1965). This may be involved, along with other properties, in the relatively high coagulant demand of I. galbana.

\section{Residual coagulant in media following coagulation}

For a series of jar tests involving $T$. suecica the residual $\mathrm{Fe}^{3+}$ in the supernatants was analysed for different coagulant dosages. In all cases, the residual $\mathrm{Fe}^{3+}$ concentration was $<2.5 \%$ of the amount dosed, increasing from $<0.02 \mathrm{mg} \mathrm{L}^{-1}$ at $1 \mathrm{mg} \mathrm{L}^{-1}$ to $0.08 \mathrm{mg} \mathrm{L}^{-1}$ at the upper dose of 5 and $6 \mathrm{mg} \mathrm{L}^{-1} \mathrm{Fe}^{3+}$. (Note that the culture medium initially contained $2 \mathrm{mg} \mathrm{Fe}^{3+} \mathrm{L}^{-1}$ but $<0.02 \mathrm{mg} \mathrm{L}^{-1}$ was detected after a blank jar test, i.e. when cells were removed by centrifuging without addition of coagulant, indicating complete adsorption of Fe by the cells.)

Residual $\mathrm{Al}^{3+}$ was highest $\left(0.35 \mathrm{mg} \mathrm{L}^{-1}\right)$ at a dose of $1 \mathrm{mg} \mathrm{L}^{-1}$ (final $\mathrm{pH} 8.0$ ) and decreased to $0.07 \mathrm{mg} \mathrm{L}^{-1}$ when 6 $\mathrm{mg} \mathrm{L}^{-1}$ was dosed ( $\mathrm{pH}$ 6.9). The corresponding cell recovery was $82-92 \%$ in this dose range. The measured $\mathrm{Al}^{3+}$ concentrations exceed the solubility of uncomplexed $\mathrm{Al}(\mathrm{III})$ in $0.6 \mathrm{M} \mathrm{NaCl}$ at $25^{\circ} \mathrm{C}$ (Palmer and Bell, 1994) and suggest either that fine, low-density hydrolysis products were not removed even after centrifuging or that significant amounts of $\mathrm{Al}^{3+}$ are complexed even by the small amount of soluble organic matter released by $T$. suecica (see below). Sediments were also analysed. Approximate mass balances based on estimated sediment volumes of 2-7 mL accounted for $75-100 \%$ of total Fe and 55-110\% of total Al. These results suggest that when the coagulant dose is close to optimum the residual coagulant in solution will be low so that reuse of the treated medium may be possible.

\section{Effect of chlorine}

A T. suecica suspension flocculated with Zetag 7570 began to redisperse after 15 min at doses of $1-3 \mathrm{mg} \mathrm{L}^{-1}$ and $1 \mathrm{~h}$ at $4-5 \mathrm{mg} \mathrm{L}^{-1}$ (Fig. 5). When sodium hypochlorite equivalent to 100 or $200 \mathrm{mg} \mathrm{Cl}_{2} \mathrm{~L}^{-1}\left(\sim 100-200 \mathrm{mg} / 10^{9}\right.$ cells) was added before cationic flocculant, the recovery of $T$. suecica after 5 min settling improved typically by 10-20\%. Cell recovery at longer settling times (between 30 and $120 \mathrm{~min}$ ) did not improve with $\mathrm{Cl}_{2}$, however the small amount of redispersion of individual cells noted with Zetag 7550 at long settling times was inhibited. Chlorine doses in this range are high enough to inactivate cells and evidently also promote rapid floc formation, leading to increased settling at short times. 


\section{DISCUSSION}

\section{Effects of cell size and surface area}

All else being equal, coagulant demand will be proportional to the total surface area of the suspended particles (Bernhardt and Clasen, 1991). Demand would therefore be expected to increase with increasing particle concentration at a given particle size, or with decreasing particle size at a given concentration (by mass or volume). If the concentration of cells is too low, however, the rate of aggregation may become limiting. The collision frequency and aggregation rate is proportional to the square of the number of particles present $\left(d \mathrm{~N}_{\mathrm{A}} / d t \propto \mathrm{N}_{\text {cells }}^{2}\right.$ ) (Hunter, 2001). This is one of the advantages of adding a hydrolysing, and sparingly soluble coagulant (Duan and Gregory, 2003). The concentration and nature of dissolved organics, primarily polysaccharide and protein, will also exert an influence on coagulant demand and in practice the optimum coagulant dose is likely to increase less than proportionately with cell concentration.

It is not surprising, based on cell size and surface areas, that Chlorococcum sp. and T. suecica have the lowest coagulant demand per gram of cell matter while that of $N$. salina and I. galbana is significantly higher, although for $N$. salina the difference is only a factor of 2-4 when coagulation is performed in the optimum $\mathrm{pH}$ range. It is clear from Figs 6 and 7 that cell surface area does not fully account for the variation in coagulant demand. The high demand of $D$. tertiolecta is likely to be a consequence of different surface functional groups or of EPS as suggested above, while that of I. galbana has been noted by several other authors (e.g. Boussiba et al. 1988, Lubián 1989) and attributed to motility (Sukenik et al. 1988), incompatible surface chemistry (Knuckey et al. 2006) and high ionic strength of the medium (Bilanovic et al. 1988). It may also have some relation to the fine structure of the cell surface, which is composed of a number of layers of flat, plate-like scales. It is evident in wholemount preparations for electron microscopy (Green and Pienaar 1977) that the scales can be shed under certain conditions and the loss of these scales in layers may be responsible, in part, for a higher coagulant demand.

\section{Effects of pretreatment with chlorine}

Pretreatment with oxidants has been reported both to promote and to inhibit coagulation, depending on species and dose. Thus Sukenik et al. (1987) found that an order of $\mathrm{mg} \mathrm{L}^{-1}$ doses of chlorine, ozone and chlorine dioxide reduced the viability of Scenedesmus sp., that chlorine and ozone caused the release of cell components, and that ozone and chlorine dioxide promoted alum coagulation while chlorine had the apposite effect. They concluded that released macromolecules in the presence of chlorine interfered with coagulation, while oxidative attack on the cell envelope by ozone or chlorine dioxide destabilised the dispersed cells. Plummer and Edzwald (2002) found that ozone or chlorine at 10-30 mg per $10^{9}$ cells reduced the $\mathrm{Al}^{3+}$ demand of Scenedesmus quadricauda but not of Cyclotella sp. Doses above $50 \mathrm{mg}$ per $10^{9}$ cells caused lysis of S. quadricauda. Ma and Liu (2002) reported cell removal from a mixed culture of Scenedesmus and Chlorococcum by alum coagulation to increase 
substantially after pretreatment with small doses $\left(1-5 \mathrm{mg} \mathrm{L}^{-1}\right)$ of potassium ferrate. Removal from lake water containing $\sim 10^{7}$ cells $\mathrm{L}^{-1}$ was even more marked. In the latter case the ratio of oxidant to algae was similar to that in our experiments with chlorine $\left(\sim 10^{-12} \mathrm{~mol} \mathrm{cell}^{-1}\right)$. Ma and Liu (2002) suggested that released intracellular and extracellular organic matter was functioning as a bridging flocculant, as reported earlier by Bernhardt and Clasen (1991). Cell inactivation and formation of particulate ferric hydroxide from ferrate were other mechanisms possibly contributing to cell removal. With the exception of ferric hydroxide, all of the above mechanisms could be operating in the Tetraselmis-chlorine-cationic polymer system. A small extent of oxidative attack on cell surfaces would be expected to increase their negative charge and thus increase colloidal stability at low ionic strength. Higher oxidant doses could cause the loss of surface macromolecules that confer steric stability, and thus be destabilising, particularly in seawater where charge contributes relatively little to stability. Still higher dosages of oxidant are believed to have an opposite effect, as cell lysis is pronounced. Surface charges will be more negative and the molecular weight of dissolved organic matter will be reduced (Plummer and Edzwald, 2001), adversely affecting the polymer's ability to bridge cells.

\section{Effects of taxonomic group}

One of the aims of the present project was to examine the coagulation behavior of a number of species across a range of taxonomic groups with the intention of investigating the relationship between flocculation properties and taxonomic group. Several authors have identified a need for this to be done (e.g. Williams and Laurens 2010, Sukenik et al. 1988). From a review of our results and those of others, it seems clear that the flocculation properties of a species depend on a series of physical and chemical features including cell size, cell wall structure and surface chemistry, motility, whether they are marine or freshwater species (the ionic strength of the medium) and the production and characteristics of organic substances that may end up on the cell surface or in the surrounding medium. The relationship between flocculation properties and taxonomic group will depend, therefore, on the consistency of distribution of these features within the taxonomic group being considered. In short, there is a poor correlation. We examined five species from four different classes. Traditional class level taxonomy is based on pigmentation, the number, structure and point of insertion of flagella, the chemical nature of storage products and cell wall structure and chemistry. Of the characters that are likely to affect flocculation, it is worth examining motility and cell wall structure in more detail both in terms of their effect on flocculation and their taxonomic distribution.

The number, structure and arrangement of flagella are features used to distinguish Classes, Orders and genera of algae, but it is simply whether a species is motile or not that will affect its coagulation properties. While the Eustigmatophyceae is defined in large part (and, indeed, named) by the structure of motile cells (Hibberd and Leedale 1971), which are typically heterokont, these have not been observed in Nannochloropsis. Most eustigmatophytes, in fact, are known predominantly by their non-motile cells and linked to the group by other features, such as the possession of chlorophyll $a$ and lack of chlorophyll $c$, possessed by other heterokont algae. Along similar lines, the presence and type of motile cells are important in the distinction of Chlorococcum from 
other green algal genera, but they are not often seen and only rarely in our cultures. Nannochloropsis and Chlorococcum are therefore essentially recognized as non-motile for the purposes of this discussion. Of the other genera, which are considered to be motile, there are important differences. Dunaliella is relatively strongly and perpetually motile, Isochrysis is perpetually, but only weakly, motile and Tetraselmis cells spend significant periods in a non-motile state, losing their flagella during cell division. In addition, the flagella of Tetraselmis are easily temporarily shed due to any chemical or physical shock, so that at any time there may $50 \%$ or more of the cells that are non-motile. It is significant here that the two genera showing the greatest differences in their flocculation behavior are Dunaliella and Chlorococcum and these belong to the same Class, the Chlorophyceae. What still needs to be determined is the effect that motility has on the flocculation process. Lubián (1989) and Bilanovic et al. (1988) suggest that motility in Isochrysis may result in an observed higher coagulant demand and, in the present work, of the species within the Chlorophyceae, the motile cells of D. tertiolecta had a higher coagulant demand than the non-motile cells of Chlorococcum sp., but they also differ significantly in cell wall structure and in the production of extracellular organic compounds, which may also affect coagulant demand. Flagella can be removed with physical or chemical shock and experiments with deflagellated cells could help to determine the effect that motility has on the flocculation process. Sukenik et al. (1988) observed that cells of Isochrysis pretreated with ozone oxidation to reduce motility had a reduced coagulant demand. Knuckey et al. (2006) reported acceptable levels of recovery for T.s suecica (>85\%) with $\mathrm{pH}$ induced flocculation, but poor recovery of the non-motile $N$. oculata along with the motile Isochrysis $s p .(<30 \%)$ which they attributed to incompatible surface chemistry rather than motility.

Cell wall structure and surface chemistry is also an important feature in distinguishing algal taxonomic groups and is also important in the flocculation process (Ives 1959, Morales et al. 1985, Lubián 1989, Henderson et al. 2008). While there is a general theme to the structure of the cell wall in each class, there is also significant variation on that theme within each class. The Prasinophyceae and the Prymnesiophyceae possess superficial layers of scales although the architecture and chemistry of the scales is quite different. The Prymnesiophyceae possess layers of organic (glycoprotein) scales (Romanovicz 1981), which is true for Isochrysis. One group within the Prymnesiophyceae, the coccolithophorids, possess scales mineralized with calcium carbonate (coccoliths). Most of the Prasinophyceae possess several layers of minute, but exquisitely architectured scales, while in a small number of genera, including Tetraselmis, the scales are particularly small and closely knitted together into a structure known as a theca, which is only loosely associated with the cell membrane. The particular role that these scales might have in the flocculation process is unknown. The significance here, however, is that there is too much variation at the class level to generalize that the members will behave in the same way. Indeed, at this stage, it would seem that the prudent course of action is to treat each species on its merits avoiding broad predictions based on taxonomic standing.

Other features likely to affect flocculation are cell size and the production and excretion of organic polymeric compounds (EPSs). There is no relationship between cell size and taxonomic group. Most microalgal Classes 
have species ranging in size from $\sim 2 \mu \mathrm{m}$ up to 40 or $50 \mu \mathrm{m}$ and some up to $1 \mathrm{~mm}$. We have seen, in general, an increase in coagulant demand with a decrease in cell size. Therefore, Nannochloropsis and Isochrysis had higher coagulant demands than Chlorococcum and Tetraselmis. Again, Dunaliella is the odd one out being more in the size range of the larger species, but having a greater coagulant demand than the smaller species. The variation in size within a taxonomic group and its effect on flocculation will therefore serve to mask or override the significance of belonging to that group. The effects of extracellular polymeric substances (EPS) on the flocculation process are not fully understood. The production of these substances is widespread in marine and freshwater species (Guillard and Wangersky 1958, Hellebust 1965, Bhaskar and Bhosle 2005, Henderson et al. 2008) and has been implicated in massive diatom flocculation events in the ocean (Kiørboe and Hansen 1993, Passow et al. 1994). In certain conditions, these substances can promote flocculation whereas, in others, they appear to add to the coagulant demand. The situation is further confused by the association of bacteria, which feed off the algal EPS and can also produce significant amounts of their own (Kormas 2005). There is also a relationship with the growth phase of the culture and the amount of EPS produced (Huntsman 1972, Boussiba et al. 1988). Production is highest in the early (lag) and late (stationary) stages of growth, although the amounts are insignificant in the early stages due to low cell numbers. There is no evidence that these compounds, in terms of their effects on the flocculation process, are any more or less significant to any particular taxonomic group.

In summary, there are features specific to algal groups that will affect coagulation such as cell wall structure, cell surface chemistry and, to some extent, motility. There are other features, however, such as cell size that vary significantly within and across algal classes and, in turn, serve to override the significance of taxonomic grouping on the flocculation process. It is fair to conclude that two species of the same size belonging to the same algal Class will have more comparable flocculation properties than two species of the same size belonging to different algal Classes. On the other hand, two species of different sizes belonging to the same Class may differ in flocculation behaviour more than two species of similar sizes belonging to different algal Classes. It is also safe to assume that species within the same genus will, in most cases, possess similar flocculation properties. Beyond these rather superficial generalizations, however, there is not much more that can be concluded in terms of the relationship between flocculation behavior and algal taxonomic group.

In coclusion, lipid-forming marine algae can readily be grown to dry matter concentrations in the range of 0.3$0.5 \mathrm{~g} \mathrm{~L}^{-1}$ and coagulated in high yield with aluminium sulfate or ferric sulfate. Optimum coagulant doses are around 6-10 $\mathrm{mg}$ of $\mathrm{Fe}^{3+}$ or $\mathrm{Al}^{3+}$ per gram of dry matter for T. suecica and Chlorococcum sp. but as high as 50-60 $\mathrm{mg} \mathrm{Fe}{ }^{3+} \mathrm{g}^{-1}$ or $35 \mathrm{mg} \mathrm{Al}^{3+} \mathrm{g}^{-1}$ for $N$. salina and D. tertiolecta. At these doses upwards of $95 \%$ of the cells settle out in 5 to 15 minutes. I. galbana requires still higher dosages. Raising the $\mathrm{pH}$ to 9 causes the N. salina $\mathrm{Fe}^{3+}$ demand to fall to about $10 \mathrm{mg} \mathrm{g}^{-1}$ but coagulation of D. tertiolecta shows opposite $\mathrm{pH}$ dependence and appears to be dominated by extracellular polymer. Coagulation of T. suecica and Chlorococcum sp. is effective at the naturally alkaline $\mathrm{pH}$ of the algal cultures. Cationic polyacrylamides were less effective than inorganic coagulants but use of an anionic polyacrylamide together with $\mathrm{Al}^{3+}$ or $\mathrm{Fe}^{3+}$ was beneficial in some cases. Ferric sulfate is an attractive coagulant because of its low toxicity, potentially allowing the used saline growth medium 
to be recovered and reused. Motile cells coagulated at low dose are able to redisperse after settling, but higher coagulant doses or a small dose of chlorine prevents this behaviour. Settled cells that continue to photosynthesize can also be resuspended by flotation but this effect can be prevented by keeping the coagulated suspension in the dark. The high coagulant demand of $N$. salina is due in part to its small size and high surface area, but cell surface properties also influence coagulation behaviour. The relationship of flocculation properties with algal taxonomic group is discussed and found to have varying significance.

\section{ACKNOWLEDGEMENTS}

This work was funded by an ARC linkage grant with financial support from Biofuels Pty Ltd. We thank Tina Hines and Kerrie Browne at WSC for DOC and Fe analyses. Al analyses were performed by ALS Laboratory Group, Springvale, Vic. The authors also thank Sherrie Caarels for her monitoring work and maintaining the algal cultures.

\section{LIST OF TABLES}

Table 1. Properties of algal cells

Table 2. Coagulation of microalgae with inorganic and polymeric coagulants: \% reduction in cell concentration vs. coagulant dose

Table 3. Effect of coagulant aid on 5-minute cell recovery 


\section{LIST OF FIGURES}

Fig. 1 Extent of coagulation of $T$. suecica with alum, iron(III) sulfate and Zetag 7570 as a function of coagulant dose.

Fig. 2 Extent of coagulation of T. suecica suspensions coagulated with iron(III) sulfate as a function of dose and settling time.

Fig. 3 Extent of coagulation of T. suecica suspensions coagulated with Zetag 7570 as a function of dose and settling time.

Fig. 4 Extent of coagulation of T. suecica with cationic polyacrylamides as a function of dose and settling time.

Fig. 5 Extent of coagulation of $T$. suecica suspensions coagulated with Zetag 7570 as a function of dose and settling time.

Fig. 6 Extent of coagulation of T. suecica, Chlorococcum sp., N. salina, D. tertiolecta and I. galbana with iron(III) sulfate as a function of coagulant dose.

Fig. 7 Extent of coagulation of T. suecica, Chlorococcum sp., N. salina, D. tertiolecta and I. galbana with alum as a function of coagulant dose.

Fig. 8 Extent of coagulation of $N$. salina suspensions as a function of iron dose: effect of $\mathrm{NaOH}$ addition.

Fig. 9 Extent of coagulation of $N$. salina suspensions as a function of alum dose: effect of $\mathrm{NaOH}$ addition.

Fig. 10 Dissolved organic carbon concentration as a function of culture age 
Table $1 \quad$ Properties of algal cells

\begin{tabular}{|c|c|c|c|c|c|c|c|}
\hline Species & Class & shape & $\begin{array}{c}\text { size/cell } \\
\text { length } \mathrm{x} \text { width } \mathrm{x} \text { depth }\end{array}$ & $\begin{array}{c}\text { SA / cell } \\
\mu \mathrm{m}^{2}\end{array}$ & $\begin{array}{c}\text { SA / g DW } \\
\mu \mathbf{m}^{2} \mathrm{~g}^{-1}\end{array}$ & $\begin{array}{c}\text { \# cells / g DW } \\
\mathrm{g}^{-1}\end{array}$ & $\begin{array}{c}\mathrm{OD}_{750} \text { of } 1 \mathrm{~g} \mathrm{~L}^{-1} \\
\text { suspension }\end{array}$ \\
\hline T. suecica & Prasinophyceae & ellipsoid & $13.16 \times 8.56 \times 5.02$ & 242.7 & $9.94 \times 10^{11}$ & $4.10 \times 10^{09}$ & 1.085 \\
\hline Chlorococcum sp. & Chlorophyceae & spherical & 9.81 (diameter) & 302.2 & $7.26 \times 10^{11}$ & $2.40 \times 10^{09}$ & 0.984 \\
\hline N. salina & Eustigmatophyceae & ellipsoid & $3.05 \times 2.60 \times 2.03$ & 20.6 & $4.44 \times 10^{12}$ & $2.15 \times 10^{11}$ & 2.201 \\
\hline D. tertiolecta & Chlorophyceae & ellipsoid & $10.15 \times 5.79 \times 5.79$ & 160.9 & $2.04 \times 10^{12}$ & $1.27 \times 10^{10}$ & 1.974 \\
\hline I. galbana & Prymnesiophyceae & ellipsoid & $6.01 \times 3.31 \times 2.88$ & 50.2 & $4.45 \times 10^{12}$ & $8.87 \times 10^{10}$ & 1.970 \\
\hline
\end{tabular}


Table 2 Coagulation of microalgae with inorganic and polymeric coagulants: $\%$ reduction in cell concentration vs coagulant dose (5 min settling)

\begin{tabular}{|c|c|c|c|c|c|c|c|c|c|c|c|c|c|}
\hline Coagulant: & $\mathbf{A l}(\mathbf{I I I})$ & Dose $\mathrm{mg} \mathrm{L}^{-1}$ : & $\mathbf{0}$ & 1 & 2 & 3 & 4 & 5 & 6 & 8 & 12 & 20 & pH range \\
\hline Species & \multicolumn{2}{|c|}{$\begin{array}{l}\text { Initial concentration } \\
\text { g DW L L }\end{array}$} & & & & & & & & & & & \\
\hline T. suecica & \multicolumn{2}{|c|}{0.346} & 4.5 & 94.7 & & 97.5 & & 91.5 & & & & & 8.76-7.96 \\
\hline T. suecica & \multicolumn{2}{|c|}{0.340} & 8.4 & 84.3 & 91.1 & 91.9 & & & 89.4 & & & & $8.23-6.88$ \\
\hline Chlorococcum sp. & \multicolumn{2}{|c|}{0.415} & 1.0 & 52.0 & 75.5 & & 90.7 & & 90.4 & & & & $9.56-8.71$ \\
\hline N. salina & \multicolumn{2}{|c|}{0.338} & 0.4 & & & & 69.7 & & 78.3 & 81.6 & 82.3 & 70.9 & $9.39-6.13$ \\
\hline N. salina & \multicolumn{2}{|c|}{0.413} & 3.5 & & & & & 68.5 & & 81.6 & 86.6 & 87.5 & $9.84-6.94$ \\
\hline D. tertiolecta & \multicolumn{2}{|c|}{0.245} & 7.0 & 7.6 & 6.6 & 2.3 & 7.6 & & 96.3 & 98.3 & 98.3 & & $8.86-6.90$ \\
\hline D. tertiolecta & \multicolumn{2}{|c|}{0.319} & 3.7 & & & 0.5 & 2.1 & & 1.0 & 17.6 & 94.8 & & \\
\hline I. galbana & \multicolumn{2}{|c|}{0.177} & 1.7 & & & 12.0 & & 37.5 & & & 93.1 & & $9.45-5.25$ \\
\hline Coagulant: & $\mathrm{Fe}(\mathrm{III})$ & Dose $\mathrm{mg} \mathrm{L}^{-1}$ : & $\mathbf{0}$ & 1 & 2 & 3 & 4 & 5 & 6 & 8 & 12 & 20 & pH range \\
\hline Species & \multicolumn{2}{|c|}{$\begin{array}{c}\text { Initial concentration } \\
\text { g DW } \mathrm{L}^{-1}\end{array}$} & & & & & & & & & & & \\
\hline T. suecica & \multicolumn{2}{|c|}{0.318} & 22.0 & & 92.5 & 95.4 & 94.2 & & 93.0 & 95.9 & & & $8.56-8.16$ \\
\hline T. suecica & \multicolumn{2}{|c|}{0.342} & 0.0 & & 98.7 & & 97.6 & & 96.5 & 95.1 & & & $8.78-8.45$ \\
\hline Chlorococcum sp. & \multicolumn{2}{|c|}{0.407} & 0.3 & & 92.0 & 97.3 & 94.8 & & 92.8 & 91.3 & & & $9.73-9.13$ \\
\hline N. salina & \multicolumn{2}{|c|}{0.342} & 0.0 & & & & 46.5 & & 59.6 & 74.5 & 82.2 & 95.0 & $9.05-7.25$ \\
\hline N. salina & \multicolumn{2}{|c|}{0.414} & 2.1 & & & 56.5 & & 84.0 & & 89.6 & 94.7 & 97.5 & $9.89-8.92$ \\
\hline D. tertiolecta & \multicolumn{2}{|c|}{0.248} & 10.4 & & 9.2 & 12.9 & 19.2 & & 64.5 & 90.4 & 97.1 & 98.2 & $8.86-7.15$ \\
\hline D. tertiolecta & \multicolumn{2}{|c|}{0.326} & 2.0 & & & 4.7 & 6.1 & & 5.1 & 12.6 & 59.8 & & \\
\hline I. galbana & \multicolumn{2}{|c|}{0.179} & 0.0 & & & 5.7 & & 15.9 & & & 43.8 & & $9.57-8.98$ \\
\hline I. galbana & \multicolumn{2}{|c|}{0.168} & 0.0 & & & & & & & & 28.1 & 60.1 & $9.44-8.41$ \\
\hline Coagulant: & Zetag 7570 & Dose $\mathrm{mg} \mathrm{L}^{-1}$ : & $\mathbf{0}$ & 1 & 2 & 3 & 4 & 5 & 6 & 8 & 12 & 20 & pH range \\
\hline Species & \multicolumn{2}{|c|}{$\begin{array}{l}\text { Initial concentration } \\
\text { g DW } \mathrm{L}^{-1}\end{array}$} & & & & & & & & & & & \\
\hline T. suecica & \multicolumn{2}{|c|}{0.303} & & 87.2 & 89.1 & 92.4 & 91.2 & 89.6 & & & & & $8.71-8.66$ \\
\hline T. suecica & \multicolumn{2}{|c|}{0.285} & 10.4 & 73.8 & 73.5 & 74.1 & 79.6 & 79.9 & & & & & \\
\hline N. salina & \multicolumn{2}{|c|}{0.418} & 3.8 & & & 9.2 & & 9.0 & & 9.3 & 10.2 & 10.9 & \\
\hline
\end{tabular}


Table 3 Effect of coagulant aid on cell recovery after 5 minute settling

\begin{tabular}{|c|c|c|c|c|c|c|c|c|c|c|c|c|c|c|}
\hline \multicolumn{3}{|c|}{ Coagulant ion dose $\mathrm{mg} \mathrm{L}^{-1}$ : } & 3 & 3 & 3 & 5 & 5 & 5 & 6 & 6 & 8 & 8 & 12 & 12 \\
\hline \multicolumn{3}{|c|}{ Magnafloc 919 dose $\mathrm{mg} \mathrm{L}^{-1}$ : } & $\mathbf{0}$ & 1 & 2 & $\mathbf{0}$ & 1 & 2 & $\mathbf{0}$ & 1 & $\mathbf{0}$ & 1 & 0 & 1 \\
\hline Species & $\begin{array}{c}\text { Initial } \\
\text { concentration } \\
\text { g DW L L } L^{-1}\end{array}$ & coagulant & & & & & & & & & & & & \\
\hline T. suecica & 0.360 & $\mathrm{Al}^{3+}$ & 24.6 & 96.2 & 96.2 & 88.7 & 93.6 & 95.9 & & & & & & \\
\hline T. suecica & 0.457 & $\mathrm{Al}^{3+}$ & 87.9 & 96.3 & 96.0 & 89.3 & 96.8 & 95.2 & 89.4 & & & & & \\
\hline N. salina & 0.397 & $\mathrm{Al}^{3+}$ & 29.0 & 28.6 & & & & & 69.2 & 73.7 & 72.1 & 83.5 & & \\
\hline N. salina & 0.362 & $\mathrm{Fe}^{3+}$ & 91.1 & 85.7 & & & & & 95.0 & 95.7 & 96.5 & 97.8 & & \\
\hline N. salina & 0.396 & $\mathrm{Fe}^{3+}$ & & & & & & & 57.7 & 54.1 & & & 83.1 & 83.8 \\
\hline
\end{tabular}




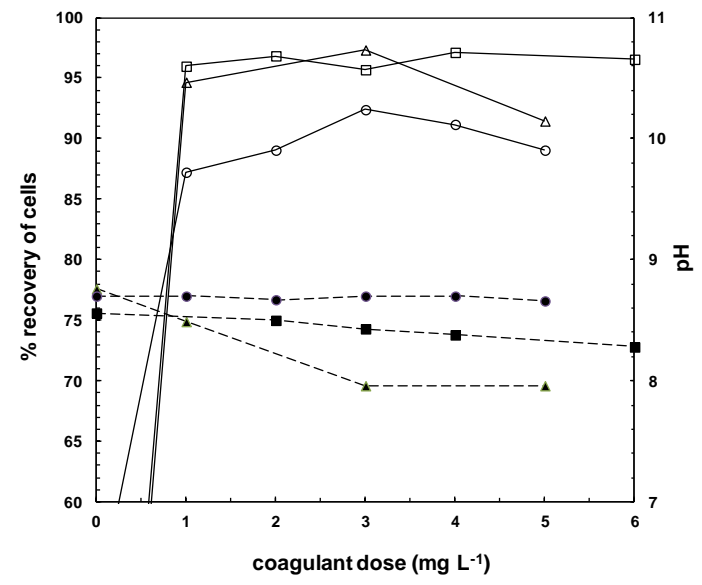

Fig. 1 Extent of coagulation of $T$. suecica with $\triangle$ alum, $\square$ iron(III) sulphate and $\circ$ Zetag 7570 as a function of coagulant dose. Final $\mathrm{pH}$ is also shown in closed symbols. (Initial concentration 0.30-0.34 g DW L $\mathrm{L}^{-1} .2$ min rapid mix, 15 min slow mix, 5 min settling)

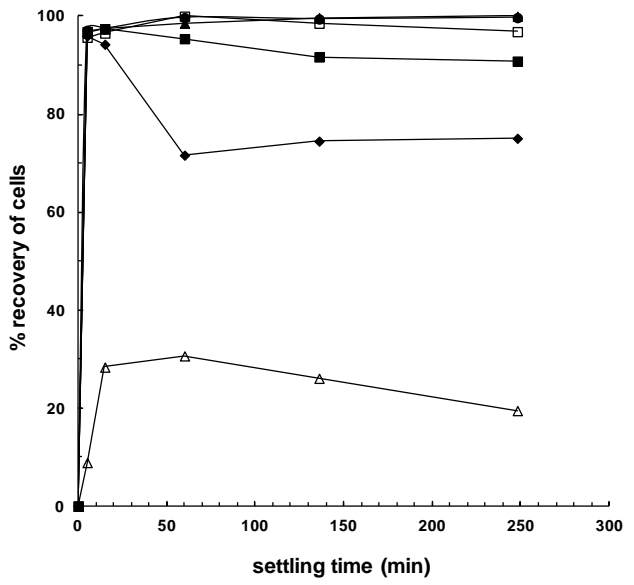

Fig. 2 Extent of coagulation of $T$. suecica suspensions coagulated with iron(III) sulfate as a function of dose and settling time. (Initial concentration $0.32 \mathrm{~g} \mathrm{~L}^{-1}, 2$ min rapid mix, $15 \mathrm{~min}$ slow mix) $\triangle 0 \mathrm{mg} \mathrm{L}{ }^{-1} \diamond 1 \mathrm{mgL}^{-1}$ - $2 \mathrm{mg} \mathrm{L}^{-1} \square 3 \mathrm{mg} \mathrm{L}^{-1} \bullet 4 \mathrm{mg} \mathrm{L}^{-1} \boldsymbol{\Delta} 6 \mathrm{mg} \mathrm{L}^{-1}$ 


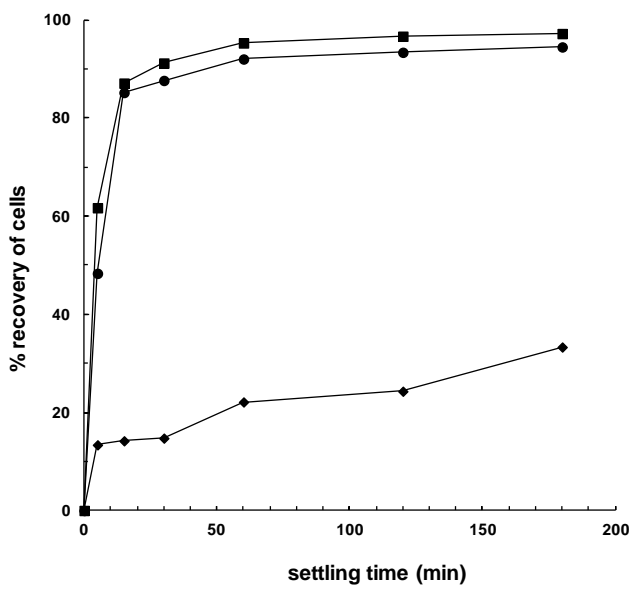

Fig. 3 Extent of coagulation of $T$. suecica suspensions coagulated with Zetag 7570 as a function of dose and settling time. (Initial concentration $0.34 \mathrm{~g} \mathrm{DW} \mathrm{L}{ }^{-1} .2$ min rapid mix, 15 min slow mix) $\bullet 0 \mathrm{mg} \mathrm{L}^{-1} \bullet 3 \mathrm{mg} \mathrm{L}^{-1}$ - $5 \mathrm{mg} \mathrm{L}{ }^{-1}$

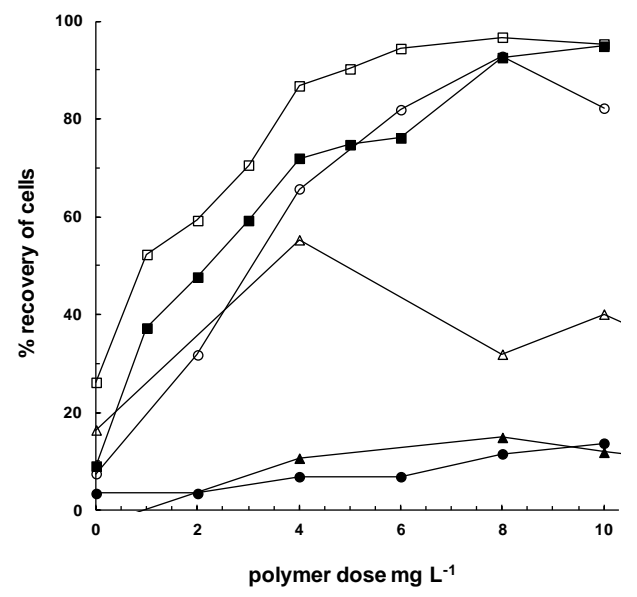

Fig. 4 Extent of coagulation of $T$. suecica with cationic polyacrylamides as a function of dose and settling time. (Initial concentration 0.29-0.40 g DW L ${ }^{-1} .2$ min rapid mix, 15 min slow mix) —Zetag $8190 \bullet$ Zetag 8180, \ Zetag 8140. Closed symbol 5 minutes settling, Open symbol 30 minutes settling 


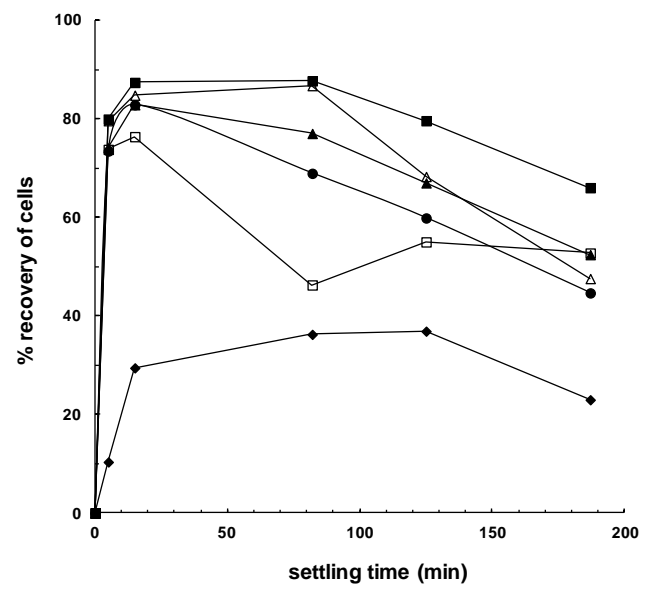

Fig. 5 Extent of coagulation of $T$. suecica suspensions coagulated with Zetag 7570 as a function of dose and settling time. (Initial concentration $0.29 \mathrm{~g} \mathrm{~L}^{-1}, 2$ min rapid mix, 15 min slow mix) $\diamond 0 \mathrm{mg} \mathrm{L}^{-1} \square 1 \mathrm{mg} \mathrm{L}^{-1}$ - $2 \mathrm{mg} \mathrm{L}{ }^{-1} \Delta 3 \mathrm{mg} \mathrm{L}^{-1} \triangle 4 \mathrm{mg} \mathrm{L}^{-1} \backsim 5 \mathrm{mg} \mathrm{L}^{-1}$

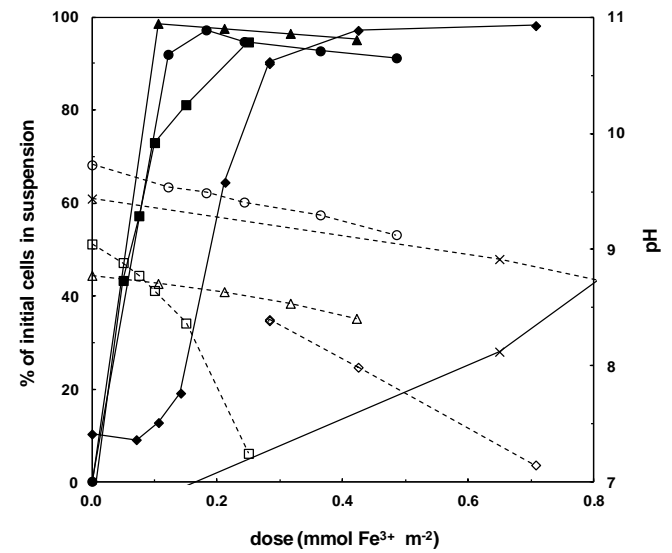

Fig. 6 Extent of coagulation and final $\mathrm{pH}$ of $\boldsymbol{\Delta}$ T. suecica, $\bullet$ Chlorococcum sp., $\boldsymbol{\bullet}$. salina, $\bullet$ D. tertiolecta and $\mathrm{X}$ I. galbana with iron(III) sulfate as a function of coagulant dose per unit surface area. (Initial concentration: $0.34 \mathrm{~g} \mathrm{~L}^{-1}$ T. suecica, $0.41 \mathrm{~g} \mathrm{~L}^{-1}$ Chlorococcum sp., $0.34 \mathrm{~g} \mathrm{~L}^{-1}$ N. salina, $0.25 \mathrm{~g} \mathrm{~L}^{-1}$ D. tertiolecta, $0.17 \mathrm{~g} \mathrm{~L}^{-1}$ I. galbana; 2 min rapid mix, 15 min slow mix, 5 min settling. 


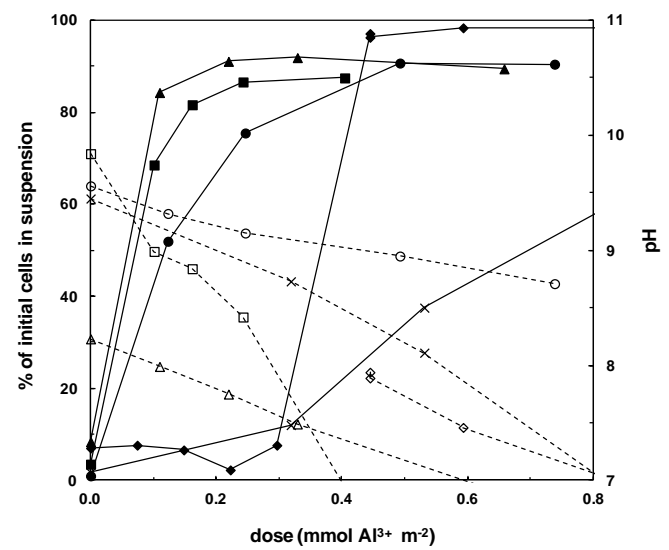

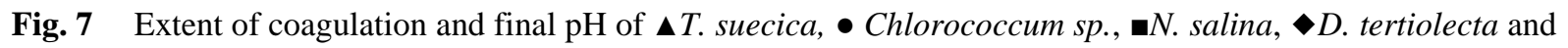
X I. galbana with alum as a function of coagulant dose per unit surface area. (Initial concentration: $0.34 \mathrm{~g} \mathrm{~L}^{-1} T$. suecica, $0.41 \mathrm{~g} \mathrm{~L}^{-1}$ Chlorococcum sp., $0.41 \mathrm{~g} \mathrm{~L}^{-1}$ N. salina, $0.25 \mathrm{~g} \mathrm{~L}^{-1}$ D. tertiolecta, $0.18 \mathrm{~g} \mathrm{~L}^{-1}$ I. galbana; $2 \mathrm{~min}$ rapid mix, 15 min slow mix, 5 min settling).

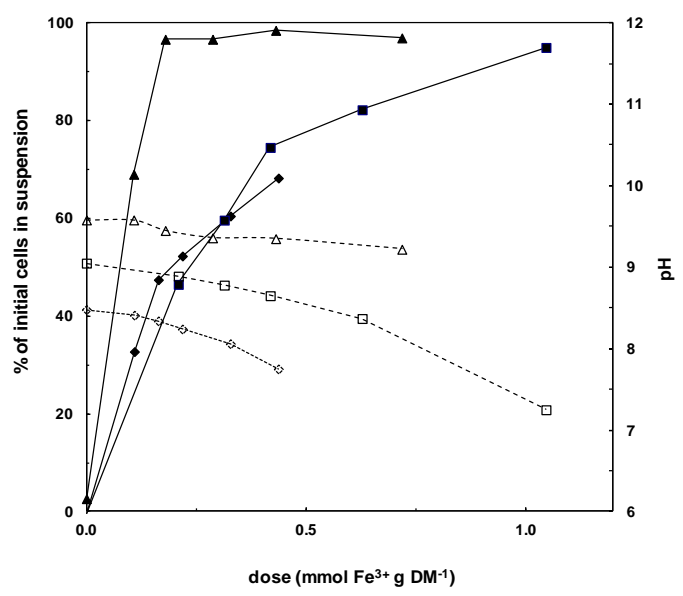

Fig. 8 Extent of coagulation of $N$. salina suspensions as a function of iron dose: effect of $\mathrm{NaOH}$ addition.

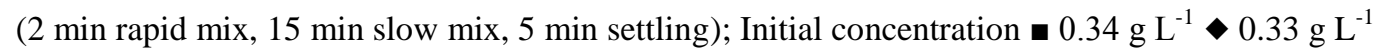

\ $0.51 \mathrm{~g} \mathrm{~L}^{-1}+\mathrm{NaOH}$. Open symbols represent $\mathrm{pH}$. 


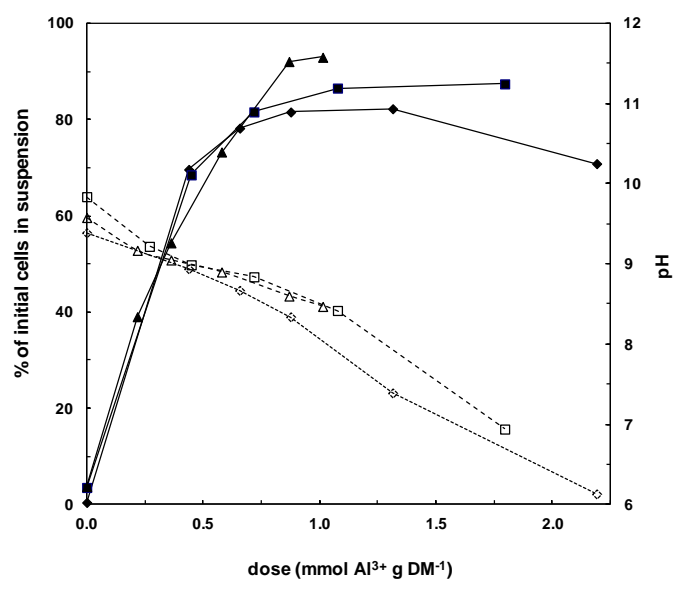

Fig. 9 Extent of coagulation of $N$. salina suspensions as a function of alum dose: effect of $\mathrm{NaOH}$ addition. (2 min rapid mix, 15 min slow mix, 5 min settling); Initial concentration $\bullet 0.34 \mathrm{~g} \mathrm{~L}^{-1} \bullet 0.41 \mathrm{~g} \mathrm{~L}^{-1} \boldsymbol{\Delta} 0.51 \mathrm{~g} \mathrm{~L}^{-1}+$ $\mathrm{NaOH}$. Open symbols represent $\mathrm{pH}$

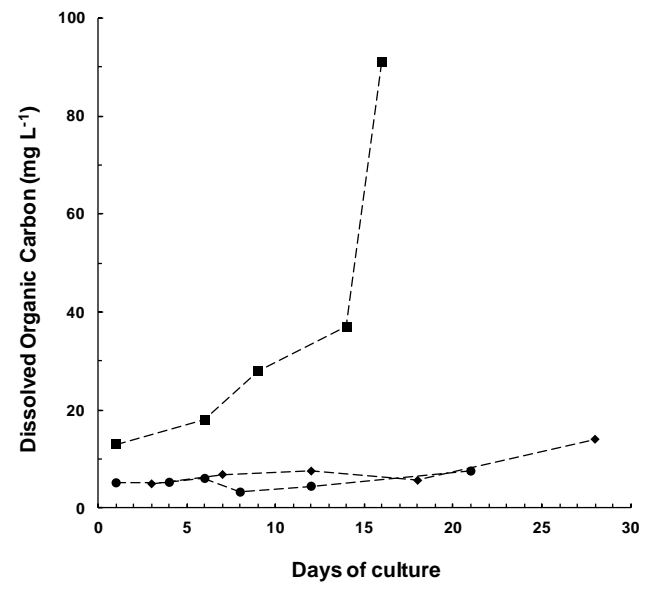

Fig. 10 Dissolved organic carbon concentration as a function of age for: $\Delta$ T. suecica, $\bullet$ N. salina, - D. tertiolecta 


\section{REFERENCES}

Bernhardt H, Clasen J (1991) Flocculation of micro-organisms. J Water Supply Res T 40(2): 76-87.

Bilanovic D, Shelef G, Sukenik A (1988) Flocculation of microalgae with cationic polymers-effects of medium salinity. Biomass 17: 65-76.

Bhaskar PV, Bhosle NB (2005) Microbial extracellular polymeric substances in marine biogeochemical processes. Curr Sci India 88: 45-53.

Bolto B, Gregory J (2007) Organic polyelectrolytes in water treatment. Water Res 41: 2301-2324.

Borowitzka MA, Siva CJ (2007) The taxonomy of the genus Dunaliella (Chlorophyta) with emphasis on the marine and halophilic species. J Appl Phycol 19: 567-590.

Boussiba S, Sandbank E, Shelef G, Cohen Z, Vonshak A, Ben-Amotz A, Arad S, Richmond A (1988) Outdoor cultivation of the marine microalga Isochrysis galbana in open reactors. Aquaculture 72: 247 - 253.

Chen L, Li P, Liu Z, Jiao Q (2009). The released polysaccharide of the cyanobacterium Aphanothece halophytica inhibits flocculation of the alga with ferric chloride. J Appl Phycol 21: 327-331

Duan J, Gregory J (2003). Coagulation by hydrolysing metal salts. Adv Colloid Interfac 100: 475-502.

Gelin F, Boogers L, Noordeloos AAM, Sinninghe Damsté JS, Riegman R, De Leeuw JW (1996) Resistant biomacromolecules in marine microalgae of the classes Eustigmatophyceae and Chlorophyceae: Geochemical Implications. Org Ceochem 26: 659-675.

Gelin F, Volkman JK, Largeau C, Derenne S, Sinninghe Damsté JS, De Leeuw JW (1999) Distribution of aliphatic, nonhydrolyzable biopolymers in marine microalgae. Org Geochem 30: 147-159.

Green JC, Pienaar RN (1977) The taxonomy of the order Isochrysidales (Prymnesiophyceae) with special reference to the genera Isochrysis Parke, Dicrateria Parke and Imantonia Reynolds. J Mar Bio Ass UK 57: 7-17.

Guillard RRL, Ryther JH (1962) Studies of marine planktonic diatoms. I. Cyclotella nana Hustedt and Detonula confervacea (Cleve). Gran. Can J Microbiol 8: 229-239.

Guillard RRL, Wangersky PJ (1958) The production of extracellular carbohydrates by some marine flagellates. Limnol Oceanog. 3: 449-454.

Hellebust JA (1965) Excretion of some organic compounds by marine phytoplankton. Limnol. Oceanogr 10: 192-206.

Henderson RK, Parsons SA, Jefferson B (2008) Surfactant as bubble surface modifiers in the flotation of algae: dissolved air flotation that utilizes a chemically modified bubble surface. Environ Sci Technol 42: 4883-4888

Hibberd DJ, Leedale GF (1971) A new algal class - the Eustigmatophyceae. Taxon 20: 523-525.

Hunter RJ (2001) Foundations of colloid science. Oxford University Press, New York, 616pp.

Huntsman SA (1972) Organic excretion by Dunaliella tertiolecta. J Phycol 8: 59-63. 
Ives K (1959) The significance of surface electric charge on algae in water purification. J Biochem Microbiol Tech Eng 1: 37-47.

Kiørboe T, Hansen JLS (1993) Phytoplankton aggregate formation: observations of patterns and mechanisms of cell sticking and the significance of exopolymeric material. J Plankton Res 15: 993 - 1018.

Knuckey R, Brown M, Robert R, Frampton D (2006). Production of microalgal concentrates by flocculation and their assessment as aquaculture feeds. Aquacult Eng 35: 300-313.

Kormas KA (2005) Bacterioplankton growth on extracellular organic carbon from marine microalgal cultures. Biol Mar 46: 241 - 251.

Levy N, Magdassi S, Bar-Or Y (1992). Physico-chemical aspects in flocculation of bentonite suspensions by a cyanobacterial bioflocculant. Water Res 26: 249-254.

Lubián LM (1989) Concentrating cultured marine microalgae with chitosan. Aquacult Eng 8: 257- 265.

Ma J, Liu W (2002). Effectiveness and mechanism of potassium ferrate(VI) preoxidation for algae removal by coagulation. Water Res 36: 871-878.

Marker AFH (1965). Extracellular carbohycrates liberation in the flagellates Isochrysis galbana and Prymnesium parvum. J Mar Biol Ass UK 45: 755-772.

McGarry M (1970) Algal flocculation with aluminum sulfate and polyelectrolytes. Res J Water Pollut C 42: 191201.

Miller DH (2006) Cell wall chemistry and ultrastructure of Chlorococcum oleofaciens (Chlorophyceae). J Phycol 14: 189-194.

Morales J, de la Noüe J, Picard G (1985). Harvesting marine microalgae species by chitosan flocculation. Aquacult Eng 4: 257-270.

Oliveira L, Bisalputra T, Antia NJ (1980) Ultrastructural observation of the surface coat of Dunaliella tertiolecta from staining with cationic dyes and enzyme treatments. New Phytol 85: 385-392.

Palmer DA, Bell JLS (1994) Aluminum speciation and equilibria in aqueous solution: IV. A potentiometric study of aluminum acetate complexation in acidic $\mathrm{NaCl}$ brines to $150^{\circ} \mathrm{C}$. Geochim Cosmochim Acta 58: 65 1-659.

Parke M (1949) Studies on marine flagellates. J Mar Biol Ass UK 28: 255 - 288.

Passow U, Alldredge AL, Logan BE (1994) The role of particulate carbohydrate exudates in the flocculation of diatom blooms. Deep Sea Res 41: 335 - 357.

Pieterse AJH, Cloot A (1997) Algal cells and coagulation, flocculation and sedimentation processes. Water Sci Technol 36: 111-118.

Plummer J D, Edzwald JK (2001) Effect of ozone on algae as precursors for trihalomethane and haloacetic acid production. Env Sci Technol 35: 3661-3668.

Plummer JD Edzwald JK (2002) Effects of chlorine and ozone on algal cell properties and removal of algae by coagulation. J Water Supply Res T 51: 307-318.

Pushparaj B, Pelosi E, Torzillo G, Materassi R (1993) Microbial biomass recovery using a synthetic cationic polymer. Biores Technol 43: 59-62. 
Romanovicz DK (1981) Scale formation in flagellates. In: Kiermayer, O. [Ed.] Cytomorphogenesis in plants; Cell Biology Monographs, Vol. 8. Springer-Verlag, Berlin, pp. 27 - 62.

Salehizadeh H, Shojaosadati SA (2001) Extracellular biopolymeric flocculants - recent trends and biotechnological importance. Biotechnol Adv 19: 371-385.

Sukenik A, Teltch B, Wachs AW, Shelef G, Nir I, Levanon D (1987) Effect of oxidants on microalgal flocculation. Water Res 21: 533-539.

Sukenik A, Bilanovic D, Shelef G (1988) Flocculation of microalgae in brackish and sea waters. Biomass 15: $187-199$.

Tenney M, Echelberger W, Schuessler R, Pavoni J (1969) Algal flocculation with synthetic organic polyelectrolytes. App Env Microbiol 18: 965-971.

Williams PJB, Laurens LML (2010) Microalgae as biodiesel \& biomass feedstocks: review \& analysis of the biochemistry, energetics \& economics. Energy Env Sci 3: 554-590. 


\section{University Library}

\section{- M M I N E R VA A gateway to Melbourne's research publications}

Minerva Access is the Institutional Repository of The University of Melbourne

Author/s:

Eldridge, RJ;Hill, DRA;Gladman, BR

Title:

A comparative study of the coagulation behaviour of marine microalgae

Date:

2012-12-01

Citation:

Eldridge, R. J., Hill, D. R. A. \& Gladman, B. R. (2012). A comparative study of the coagulation behaviour of marine microalgae. JOURNAL OF APPLIED PHYCOLOGY, 24 (6), pp.1667-1679. https://doi.org/10.1007/s10811-012-9830-4.

Persistent Link:

http://hdl.handle.net/11343/283320 